\section{Iron Deficiency Anemia Induced Thrombocytopenia: A Report of Two Cases}

Sir,

Iron deficiency anemia (IDA) mostly causes reactive thrombocytosis. ${ }^{1}$ However, thrombocytopenia has also been reported rarely, especially when the hemoglobin $(\mathrm{Hb})$ level is $<\mathrm{z} 7 \mathrm{~g} / \mathrm{dL}{ }^{1}$ Thrombocytopenia may also be observed in various other conditions such as infections, malignancies, drugs, connective tissue diseases, idiopathic thrombocytopenic purpura, and megaloblastic anemia. ${ }^{2}$ Thrombocytopenia may be corrected after iron supplementation in an isolated IDA. ${ }^{3}$ In this report, we present two patients with thrombocytopenia associated with IDA, and review the relevant literature.

A 25-year male was admitted with complaints of fatigue, weakness, and purpuric lesions on extremities. He had no history of previous illness or medication. In physical examination, blood pressure was $120 / 70 \mathrm{mmHg}$, and the heart rate was $100 \mathrm{bpm}$. He looked pale. Lymphadenopathy or organomegaly was not detected. Other system examinations were normal. In laboratory findings, $\mathrm{Hb}$ was $6.5 \mathrm{~g} / \mathrm{dL}$ platelets $13 \times 10^{9} / \mathrm{L}$, mean corpuscular volume (MCV) $63 \mathrm{fL}$, red cell distribution width (RDW) 30.6 , serum iron $10 \mu \mathrm{g} / \mathrm{dL}$, total iron-binding capacity $336 \mu \mathrm{g} / \mathrm{dL}$, and serum ferritin $1.5 \mu \mathrm{g} / \mathrm{dL}$. Vitamin B12 and folate levels were normal. Anti-nuclear antibody (ANA), rheumatoid factor (RF), and viral markers were normal. Other biochemical parameters were normal. The peripheral blood smear showed anisocytosis, and microcytic-hypochromic cells with thrombocytopenia. No platelet clumping was noticed. We started oral administration of ferrous sulfate $(270 \mathrm{mg})$ once a day. In five days, platelet count increased gradually towards normal. On the 30th day of treatment, platelet count was normal and $\mathrm{Hb}$ increased to 13.1 $\mathrm{g} / \mathrm{dL}$.

The second case comprised of a 34-year female, who presented with weakness and tiredness. Physical examination revealed facial palor. Lymphadenopathy or organomegaly was not detected. In laboratory findings, $\mathrm{Hb}$ was $4.1 \mathrm{~g} / \mathrm{dL}$, platelets $59 \times 10^{9} / \mathrm{L}$, MCV $57.2 \mathrm{fL}$, white blood cell count (WBC) $4.8 \mathrm{k} / \mathrm{uL}$, serum iron $27 \mu \mathrm{g} / \mathrm{dL}$, iron-binding capacity $664 \mu \mathrm{g} / \mathrm{dL}$,

and serum ferritin $2.9 \mu \mathrm{g} / \mathrm{mL}$. Vitamin B12 and folate levels were normal. Anisocytosis and microcytic hypochromic erythrocytes were observed in the peripheral blood smear. ANA, RF, and viral markers were normal. Active bleeding was not detected. Three units of packed red cells and intravenous iron ferroximaltose were administered. On the second and third days, platelet count was 33 and $38 \times 10^{9} / \mathrm{L}$. The peripheral blood smear was consistent with $70 \times 10^{9} / \mathrm{L}$ platelets. After two weeks, $\mathrm{Hb}$ increased to $11.2 \mathrm{~g} / \mathrm{dL}$, and platelet count increased to $75 \times 10^{9} / \mathrm{L}$.

Thrombocytopenia can be detected concurrently with IDA. ${ }^{2}$ The study conducted by Kadıköylü et al. detected thrombocytopenia in $2.3 \%$ of 86 patients with IDA. They reported that a $\mathrm{Hb}$ value below $6.5 \mathrm{~g} / \mathrm{dL}$ could cause higher erythropoietin levels, which, in turn, could cause thrombocytopenia. ${ }^{2}$ The fact that our patients' $\mathrm{Hb}$ levels were below $6.5 \mathrm{~g} / \mathrm{dL}$ supports this idea. Kuku et al., studied platelet values of 615 patients with IDA, and thrombocytopenia was found in 13 patients. ${ }^{4}$ The platelet counts of patients with thrombocytopenia ranged from $10.5 \times 10^{9} / \mathrm{L}$ to $14.5 \times 10^{9} / \mathrm{L}$. In these cases, thrombocytopenia was severe (grade 3 and 4 ). It is important to show that there may be severe thrombocytopenia in IDA. In the literature, the number of cases with IDA presenting with severe thrombocytopenia (grade 3-4) is quite low. ${ }^{2,3}$

Perlman et al. shared the data of six patients with IDA presenting with thrombocytopenia. All the cases were found to have normal platelet values within a few days of starting oral iron therapy. It was hypothesised that iron is necessary to form any biological reactions and plays a critical role in cell growth, proliferation, and DNA synthesis. This has been implicated in human hematopoietic cells, including platelets. ${ }^{3}$

To the best of our knowledge, IDA and thrombocytopenia have been reported concurrently in almost all female cases. On the other hand, only a few male patients with IDA with concurrent thrombocytopenia have been reported, as in one of these cases. ${ }^{5}$ The lower incidence of IDA-induced thrombocytopenia in males may be due to the fact that iron deficiency is much less common in males; as well as due to the differences in iron metabolism, in females and males. ${ }^{6}$

Although IDA often causes thrombocytosis, it can rarely cause thrombocytopenia. In IDA-associated thrombocytopenia, we suggest that it is appropriate to first determine whether thrombocytopenia improves with the administration of iron therapy. However, the cause of iron deficiency should also be investigated.

\section{CONFLICT OF INTEREST:}

The authors declared no conflict of interest.

\section{AUTHORS' CONTRIBUTION:}

MB: Data collection, manuscript writing.

BE: Manuscript writing.

MD: Data interpretation.

$A B$ : Data collection.

\section{REFERENCES}

1. Kadikoylu G, Yavasoglu I, Bolaman Z, Senturk T. Platelet parameters in women with iron deficiency anemia. J Natl Med Assoc 2006; 98(3):398-402. PMID: 16573304; PMCID: PMC2576122.

2. Lopas H, Rabiner SF. Thrombocytopenia associated with iron deficiency anemia. Clin Pediatr 1966; 5(10):609-16. doi: 10.1177/000992286600501008.

3. Perlman MK, Schwab JG, Nachman JB, Rubin CM. Thrombocytopenia in children with severe iron deficiency. J 
PediatrHematol Oncol 2002; 24(5):380-4. doi: 10.1097/ 00043426-200206000-00011.

4. Kuku I, Kaya E, Yologlu S, Gokdenız R, Baydın A. Platelet counts in adults with iron deficiency anemia. Platelets 2009; 20(6):401-5. doi: 10.1080/09537100903137306.

5. Cunha V, Ferreira M, Barosa R, Fonseca AG, Delerue F, Carvalho $C$. Iron-induced thrombocytopenia in severe irondeficiency anemia. Expert Rev Hematol Early 2015; 1-5. doi: 10.1586/17474086.2015.1010504.

6. Harrison-Findik DD. Gender-related variations in iron metabolism and liver diseases. World J Hepatol 2010; 2(8):302-10. doi: 10.4254/wjh.v2.i8.302.
Metin Bağci, Batuhan Erdogdu, Mehmet Dagli and Abdulkadir Basturk

Department of Hematology, Faculty of Medicine, Selcuk Univercity Konya, Turkey

Correspondence to: Dr. Metin Bağci, Department of Hematology, Faculty of Medicine, Selcuk Univercity Konya,

Turkey

E-mail:drmetinbagci@gmail.com

Received: February 21, 2020; Revised: September 18, 2020;

Accepted: October 15, 2020

DOI: https://doi.org/10.29271/jcpsp.2021.02.245 